\title{
PELATIHAN CLASSROOM TASK UNTUK GURU PAUD DI DESA PALINGGIHAN KECAMATAN PLERED KABUPATEN PURWAKARTA
}

\author{
Cynantia Rachmijati $^{1 *}$, Anita Anggraeni ${ }^{1}$, Aseptiana Parmawati ${ }^{1}$ \\ ${ }^{I}$ Program Studi Pendidikan Bahasa Inggris Fakultas Bahasa, IKIP Siliwangi, Cimahi, Indonesia \\ *Penulis korespondensi: cynantiarachmijati@ikipsiliwangi.ac.id
}

\begin{abstract}
Abstrak
Anak-anak usia dini secara umum di Desa Palinggihan daerah Purwakarta ini masih belum mendapatkan pelatihan dan exposure terkait bahasa Inggris karena masih jarangnya pelatihan TEYL untuk para guru pengajar PAUD. Terlebih latar belakang pendidikan para guru cenderung tidak sesuai dengan bidang yang diajar. Berdasarkan penjelasan diatas, berikut ini merupakan beberapa masalah yang dapat diidentifikasi: 1) pembelajaran TEYL yang masih belum optimal 2) belum adanya pemahaman dari para guru PAUD tentang pentingnya classroom task dalam pembelajaran bahasa inggris bagi anak-anak usia dini. Metode yang dilaksanakan dalam kegiatan pengabdian masyarakat ini adalah pelatihan kepada para guru PAUD dengan menggunakan optimalisasi media gambar. Pelatihan yang diberikan berupa pelatihan classroom task yang meliputi: 1) classroom language, 2) penggunaan media dan materi pembelajaran yang efektif serta menyenangkan. Berdasarkan penjelasan tersebut tim kami mengadakan kegiatan pengabdian kepada masyarakat dengan judul 'Pelatihan classroom task untuk guru paud di Desa Palinggihan Kecamatan Plered Kabupaten Purwakarta”. Kegiatan mendapatkan tanggapan positif dan diharapkan pelatihan tersebut juga diterapkan oleh para guru saat mengajar di kelas.
\end{abstract}

Kata kunci: Classroom Task, Classroom Language, TEYL.

\begin{abstract}
In general, children in the Desa Pallinggiran Purwakarta still haven't received proper training and English exposure due to the rarity of TEYL training for PAUD teachers. Moreover, the educational background of teachers tends to be incompatible with the field that being taught. Based on the explanation above, the following are some of the problems that can be identified: 1) TEYL learning which is still not optimal 2) there is no understanding from PAUD teachers about the importance of the classroom task in learning English for early childhood. The method implemented in this community service activity is training PAUD teachers using image media optimization. The training is in the form of classroom task training which includes: 1) classroom language, 2) the use of media and learning materials that are effective and fun. Based on this explanation, our team held a community service activity with the title "Classroom training for PAUD teachers in Desa Palinggihan, Plered District, Purwakarta". The activity received a positive response and it was hoped that the training would also be applied by the teachers while teaching in the classroom.
\end{abstract}

Keywords :classroom task,classroom language, TEYL.

\section{PENDAHULUAN}

Bahasa Inggris menjadi mata pelajaran muatan lokal yang wajib diajarkan di sekolah dasar. Pengenalan bahasa Inggris sejak awal didasari oleh suatu konsep pedagogis bahwa semakin dini usia seseorang diperkenalkan dengan bahasa target, semakin cepat dan semakin bagus penguasaan dan pemerolehan anak terhadap bahasa yang dipelajari (Harmer, 2007).

Secara hakiki, pembelajaran untuk anak-anak berbeda dengan pembelajaran untuk orang dewasa. Pebelajar anak-anak memiliki karakteristik yang berbeda dengan kelompok lain. Beberapa karakteristik mendasar dari anak-anak adalah mereka senang bermain dan memiliki konsentrasi yang singkat.
Dengan karakteristik tersebut, guru bahasa Inggris di sekolah dasar semestinya menggunakan strategi atau teknik mengajar yang berbeda dengan para pebelajar bahasa lainnya. Kebijakan pembelajaran bahasa Inggris sebagai mata pelajaran muatan lokal di sekolah dasar yang di mulai sejak tahun 1994 sampai dengan pemberlakuan KTSP sejak tahun 2006 belum dibarengi oleh usaha maksimal baik dari pihak pemerintah maupun sekolah, terutama guru untuk memaksimalkan pembelajaran.

Strategi atau teknik yang biasanya digunakan oleh guru dalam mengajar cenderung bersifat konvensional, yaitu setelah mengajarkan melafalkan kosakata secara berulang- ulang (drills), guru menjelaskan kosakata 
bahasa Inggris dengan menerjemahkan, yaitu memberikan padanannya dalam bahasa ibu (bahasa Indonesia). Pemanfaatan bahasa pertama (L1) bila dilakukan terlalu sering, bahkan mendominasi tidak baik atau tidak membantu siswa menguasai bahasa yang dipelajari. Oleh karena itu, guru hendaknya dapat menjadi model bahasa target dengan baik, yakni lebih banyak menggunakan bahasa Inggris di dalam kelas.

Purwakarta merupakan salah satu kabupaten yang berada di Jawa Barat. Kabupaten ini berbatasan dengan kabupaten Bandung Barat, Cianjur, Karawang, dan Subang. Sebagai salah satu kabupaten yang berada di Jawa Barat, maka mayoritas penduduknya adalah suku sunda. (BPS, 2015). Purwakarta ini meski termasuk kota yang kecil namun mengalami perkembangan yang sangat pesat, sempat mengusung slogan TASBEH (Taqwa, Aman, Sehat, Bersih, Elok dan Hijau) namun kini memakai slogan "Purwakarta Istimewa", mengartikan bahwa masyarakat mendapat keistimewaan melalui pelayanan publik dan pembangunan di segala bidang (Oktagon, 2017).

Purwakarta mengusung tema istimewa. Istimewa dalam hal ini dimaknai bahwa Purwakarta diproyeksikan agar bisa menjadi kota pusat budaya sunda. Hal ini tercermin dalam kehidupan pendidikan di lingkungan sekolah, dimana pada waktu tertentu siswa dan guru diwajibkan untuk memakai kebaya atau kampret hitam (pakaian khas sunda). Tidak hanya dalam hal berpakaian, demi menjaga budaya dan bahasa tetap terpelihara, pemerintah kabupaten Purwakarta mengharuskan siswa dan guru untuk berkomunikasi dalam bahasa sunda setiap hari Rabu.

Pendidikan di Purwakarta dapat dinilai menuju arah lebih baik, hal ini terlihat dengan kesadaran masyarakat akan pentingnya pengetahuan dan pendidikan. Hal ini juga ditandai dengan banyaknya bermunculan sekolahsekolah baru baik negeri maupun swasta dari mulai tingkat PAUD sampai sekolah tinggi. Berdasarkan keterangan kepala PAUD Nurhidayah, mulai tahun 2010 banyak berdiri PAUD di wilayah Purwakarta. Keberadaan PAUD dimotori oleh ibu-ibu pengajian di wilayah Purwakarta yang menyadari akan pentingnya pendidikan bagi anak usia dini. Sarana dan prasarana serta kualitas pendidikan juga mulai diperhatikan. Hal ini dapat dilihat dari penggunaan bahasa inggris yang mulai diaplikasikan dalam penyampaian materi untuk tingkat PAUD.

Kesadaran akan pentingnya pengenalan bahasa inggris bagi anak usia dini di wilayah Purwakarta, terutama di desa Tegalwaru berbanding terbalik dengan kualitas dan kompetensi dalam penyampaian materi berbahasa inggris yang dimiliki oleh guru pengajar tingkat PAUD di wilayah tersebut. Hal ini dipengaruhi oleh beberapa faktor, diantaranya adalah latar belakang pendidikan para guru paud yang tidak sesuai dengan bidang yang diajarkan. Selain itu minimnya pelatihan dasar dalam penggunaan bahasa inggris untuk tingkat PAUD juga jarang mereka dapatkan.
Desa Palinggihan Kecamatan Plered Kabupaten Purwakarta ini merupakan salah satu desa pendidikan. Berdasarkan penuturan Kepala Desa Bapak Kusyadi menyatakan bahwa desa ini yang terdiri atas 4 RT, 10 RW dan 2 dusun ini termasuk desa pendidikan. Penduduk di desa tersebut sejumlah $40 \%$ adalah penduduk dengan gelar S1. Fasilitas sekolah dari tingkat TK hingga SMA juga terdapat di desa ini. Namun strategi pembelajaran yang disampaikan masih metode sederhana dengan menggunakan teacher centered.

Pada proses pembelajaran, media pengajaran merupakan wadah dan penyalur pesan dari sumber pesan, dalam hal ini guru, kepada penerima pesan, dalam hal ini siswa. Dalam batasan yang lebih luas, Yusufhadi Miarso dikutip dalam Mahnun (Mahnun, 2012) memberikan batasan media pengajaran sebagai segala sesuatu yang dapat digunakan untuk merangsang pikiran, perasaan, perhatian, dan kemauan siswa sehingga mendorong terjadinya proses belajar pada diri siswa.

Apabila dilihat dari manfaatnya (Danim, 1995) menyebutkan manfaat media dalam pengajaran adalah sebagai berikut: (a) Meningkatkan mutu pendidikan dengan cara meningkatkan kecepatan belajar (b) Memberi kemungkinan pendidikan yang sifatnya lebih individual, (c) Memberi dasar pengajaran yang lebih ilmiah, (d) Pengajaran dapat dilakukan secara mantap, (e) Meningkatkan terwujudnya kedekatan belajar, dan (f) Memberikan penyajian pendidikan lebih luas.

Selain itu, dari hasil penelitian yang dilakukan oleh (Bardansyah, 2008) di temukan bahwa tingkat pencapaian pengetahuan melalui indera penglihatan mencapai $75 \%$, sementara melalui indera pendengaran hanya $13 \%$, sedangkan melalui indera lain, seperti pengecapan, sentuhan, penciuman, pengetahuan hanya dapat diperoleh sebesar $12 \%$. Lingkungan belajar yang dilengkapi dengan gambargambar memberikan dampak 3 kali lebih kuat dan mendalam daripada kata-kata (ceramah).

Media secara istilah dapat kita simak beberapa pendapat para ahli diantaranya; (Schramm, 1982) berpendapat bahwa media adalah," Information carying technologies that can be used for instruction. The media instruction, consequently are extensions of the teacher". Menurutnya media adalah teknologi pembawa pesan yang dapat dimanfaatkan untuk keperluan pembelajaran. Jadi media adalah perluasan dari guru.

Pengertian yang dikemukakannya tidak jauh beda dengan pengertian yang dikemukakan oleh Asociation of Education Comunication Technology (AECT) (AECT, 1977), yang mana media diartikan dengan segala bentuk dan saluran yang dapat dipergunakan untuk proses penyalur pesan. Dari kedua pendapat tersebut dapat dipahami bahwa media adalah berkaitan dengan perantara yang berfungsi menyalurkan pesan dan informasi dari sumber yang akan diterima oleh 
si penerima pesan yang terjadi dalam proses pembelajaran.

Terkait dengan semakin beragamnya media pengajaran (Rahadrjo, 1986) mengatakan pemilihan media hendaknya memperhatikan beberapa prinsip. Yaitu; (a) Kejelasan maksud dan tujuan pemilihan media; apakah untuk keperluan hiburan, informasi umum, pembelajaran dan sebagainya, (b) Familiaritas media, yang melibatkan pengetahuan akan sifat dan ciri-ciri media yang akan dipilih, dan (3) Sejumlah media dapat diperbandingkan karena adanya beberapa pilihan yang kiranya lebih sesuai dengan tujuan pengajaran.

Banyak penelitian diadakan mengenai media pembelajaran mana yang paling sesuai untuk tujuan tertentu, dan hasil penelitian menunjukan bahwa; 1) Tidak setiap media pengajaran dapat dimanfaatkan untuk mencapai sembarang tujuan pengajaran, 2) Semua media pengajaran dapat membantu guru dalam melaksanakan satu atau beberapa fungsi dalam pengajaran, seperti mengisahkan, mengontrol/mengecek, memberikan penguatan dan mengadakan evaluasi.

Dari semua temuan di atas, tim pelaksana kegiatan merasa berkepentingan untuk membantu para guru agar dapat meningkatkan kualitas bahasa Inggris yang digunakan di dalam kelas melalui pelatihan classroom task dengan menggunakan media gambar pada para guru yang bisa dimanfaatkan baik di tingkat SD, SMP dan SMA. Dengan pelatihan tersebut, para guru akan diperkenalkan dengan berbagai bentuk media gambar yang dapat membantu dalam pembelajaran bahasa Inggris sehingga pembelajaran bisa berjalan menjadi lebih menyenangkan dan efektif. Tujuan dari kegiatan ini adalah Untuk meningkatkan pengetahuan dan keterampilan guru-guru bahasa Inggris dalam pemberian tugas (classroom task) dalam melaksanakan pembelajaran dengan memanfaatkan media gambar

Dengan melaksanakan kegiatan ini, manfaat yang dapat dipetik antara lain:

1) Bagi Guru Bahasa Inggris

Kegiatan P2M ini memberikan masukan yang berharga berupa pengetahuan dan keterampilan praktis bagi guruguru bahasa Inggris dalam rangka mengupayakan memaksimalkan penggunaan media gambar di kelas untuk meningkatkan pemahaman siswa dalam bahasa Inggris. Dengan demikian, para guru dapat menciptakan kegiatan pembelajaran yang menyenangkan dan efektif.

\section{2) Bagi Sekolah}

Kegiatan P2M ini memberikan kontribusi positif terhadap peningkatan kualitas guru bahasa Inggris dari segi penambahan pengetahuan dan keterampilan praktis melaksanakan pembelajaran classroom task melalui optimalisasi penggunaan media gambar.
3) Bagi Siswa

Melalui pelaksanaan pelatihan ini, guru dapat lebih mengefektifkan pembelajaran bahasa Inggris menggunakan media gambar ini. Sehingga language skills siswa dalam speaking, writing dan reading bisa terasah dengan lebih baik.

\section{4) Bagi IKIP Siliwangi}

Program pengabdian kepada masyarakat adalah salah satu bagian dari tridharma perguruan tinggi. Oleh karena itu menjadi suatu kewajiban bagi setiap dosen dan sivitas akademika lainnya untuk terlibat dalam program pengabdian kepada masyarakat. Tujuan pertama dalam kegiatan ini adalah bagian dari tri dharma,sebagai kewajiban sebagai dosen dan sivitas akademik. Tujuan kedua adalah membantu para guru yang ada di Purwakarta mengembangkan keilmuan dan inovasi pembelajaran. Tujuan ketiga adalah melakukan sosialisasi dan publikasi terkait pengenalan nama kampus kepada masyarakat sekitar. Semua tujuan ini adalah tujuan jangka pendek yang diharapkan dapat diimplementasikan. Tujuan jangka panjang adalah mengembangkan program kerja sama dan pendampingan bagi para guru dalam kegiatan belajar mengajarnya.

\section{METODE}

\section{A. Sasaran}

Metode yang dipilih dalam melaksanakan kegiatan pengabdian masyarakat ini ini adalah pelatihan kepada para guru PAUD yang berada di desa Palinggihan kecamatan Plered Kabupaten Purwakarta. Para guru PAUD yang diutamakan untuk mengikuti pelatihan ini adalah mereka yang mengajar bahasa inggris, namun mereka tidak memiliki latar belakang pendidikan bahasa Inggris yang memadai. Diutamakan mereka yang menjabat sebagai guru PAUD, namun karena setelah diteliti melalui observasi lapangan ditemukan bahwa jumlah guru PAUD tidak sebanyak guru tingkat SD, SMP dan SMA sehingga sasaran pelatihan tim pelaksana kegiatan P2M ini ditujukan kepada para guru tingkat TK, SD, SMP hingga SMA sejumlah 20 orang.

\section{B. Metode Pelaksanaan Kegiatan}

Metode yang dipilih dalam melaksanakan kegiatan P2M ini adalah pelatihan terutama kepada para guru bahasa Inggris. Mereka akan diberikan pelatihan berupa pemberian classroom task dan optimalisasi media gambar sebagai upaya untuk membuat kegiatan belajar mengajar menjadi lebih efektif dan menyenangkan.

Pelatihan yang diberikan oleh tim pelaksana berupa pelatihan classroom task yang meliputi:

1. classroom task,

2. Optimalisasi penggunaan media gambar dalam kegiatan belajar mengajar, yaitu :

- Level SD adalah penggunaan flash card.

- Level SMP adalah penggunaan picture series.

- Level SMA adalah penggunaan picture prompt dan procedural picture. 
Langkah-langkah kegiatan yang ditempuh dilaksanakan dalam 4 tahap sebagai berikut ini:

1) Identifikasi permasalahan

Pada tahap ini tim pelaksana mengadakan observasi serta wawancara. Observasi dan wawancara ini dilaksanakan dengan berdiskusi dengan Kepala Desa serta mengunjungi posko para mahasiswa untuk memastikan persoalan yang dihadapi oleh para guru serta jumlah sekolah yang ada di lingkungan sekitar.

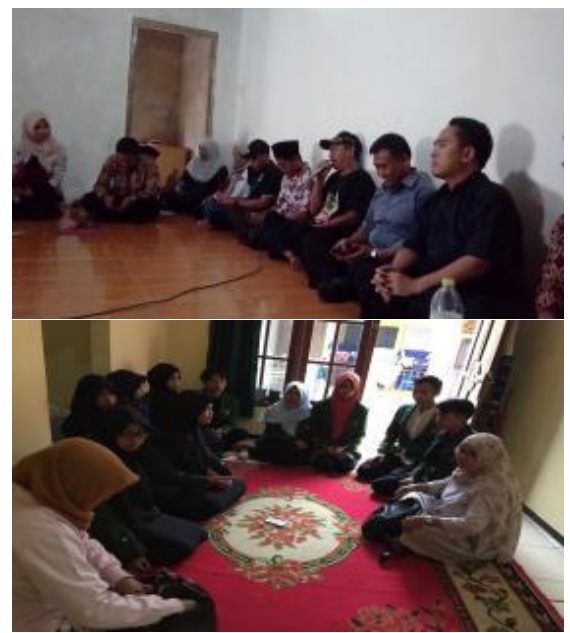

Gambar 1. Kegiatan Pelaksanaan Tahap 1.

2) Pengolahan informasi dan penentuan pemecahan masalah

Pada tahap ini tim pelaksana mengolah semua informasi baik berupa masukan hasil survei dan wawancara. Kajian teoretik dan empiris dikumpulkan terkait dengan usaha memberikan solusi terhadap masalah-masalah yang telah teridentifikasi. Adapun solusi yang segera perlu dilakukan adalah melalui pelatihan classroom task melalui optimalisasi media gambar untuk meningkatkan kualitas bahasa Inggris para guru dalam proses pembelajaran.
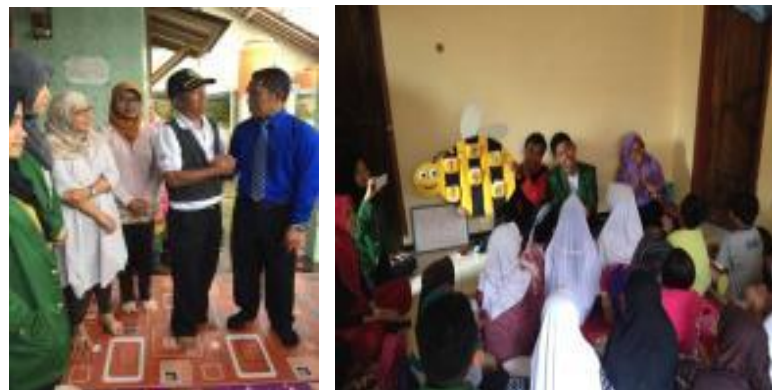

Gambar 2. Kegiatan Pelaksanaan Tahap 2.

\section{3) Penyusunan materi pelatihan}

Pada tahap ini tim pelaksana mulai menyusun materi untuk hand-out yang akan diberikan kepada para peserta pelatihan serta mencari referensi yang sesuai.

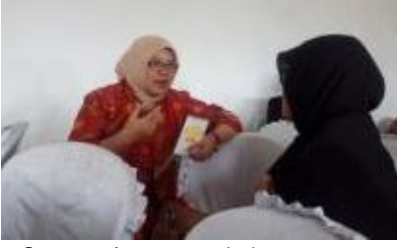

Gambar 3. Kegiatan Pelaksanaan Tahap 3.

4) Kegiatan pelaksanaan

Pada tahap ini adalah kegiatan paling penting, yaitu pelaksaan aplikasi dari pelatihan classroom task melalui optimalisasi media gambar. Kegiatan ini dilaksanakan di Ruang Kantor Desa dimana Tim pelaksana memberikan pelatihan dan penerangan materi serta peserta mengadakan praktek setelah pemberian materi diberikan.

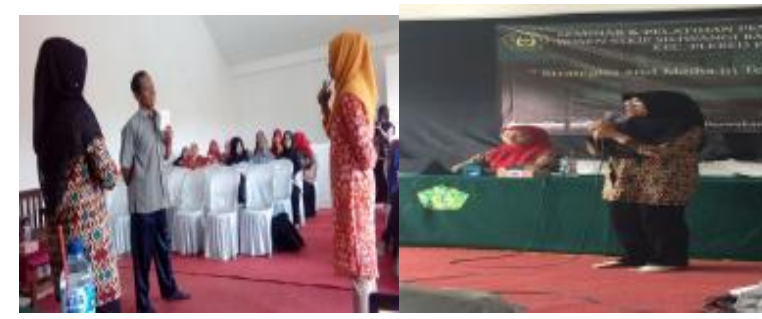

Gambar 4. Kegiatan Pelaksanaan Tahap 4.

3. HASIL DAN PEMBAHASAN

A. Peningkatkan pengetahuan dan keterampilan guruguru bahasa Inggris dalam pemberian tugas (classroom task) dalam melaksanakan pembelajaran dengan memanfaatkan media gambar.

Untuk meningkatkan pengetahuan dan keterampilan guru-guru bahasa Inggris di sekolah dalam pembelajaran bahasa Inggris pada umumnya dan optimalisasi penggunaan media gambar, beberapa konsep dipaparkan oleh narasumber antara lain:
a. Pengertian media
b. Jenis jenis media
c. Keuntungan dan kelebihan media
d. Contoh-contoh media gambar

Pada pelaksanaan seminar, para guru diberikan materi pelatihan yang komprehensif tentang classroom task dan optimalisasi penggunaan media gambar. Selanjutnya, para guru diberikan hand-out terkait materi pelajaran.

\section{Classroom task}

Setelah pemaparan panjang, maka bisa dipahami bahwa media pembelajaran itu tidak bisa lepas dari kegiatan pembelajaran. Kegiatan pembelajaran bisa berjalan lancar apabila adanya ketersediaaan bahan ajar, media, serta kreativitas dari guru itu sendiri. Media pembelajaran dapat dirancang sendiri oleh guru atau memanfaatkan dari media yang tersedia. Media pembelajaran dapat dipilih oleh guru sesuai dengan tujuan pembelajaran dan dapat dimanfaatkan di dalam kelas atau di luar kelas sesuai kegiatan belajar yang akan dilakukan siswa. Media belajar bukan menjadi "topik utama" dalam suatu kegiatan belajar mengajar, namun 
bisa membantu guru dalam menyampaikan pembelajarannya.

Media pembelajaran pada perkembangan sekarang ini sangat beragam. Ada media penyaji, media objek dan media interaktif. Media penyaji yaitu media yang mampu menyajikan informasi. Misal gambar, poster, foto (yang digunakan sebagai alat peraga), transparansi, radio, telepon, film, video, televisi, multimedia (kit). Media objek yaitu media yang mengandung informasi seperti realia, replika, modul benda tiruan. Media interaktif yaitu media yang memungkinkan untuk berinteraksi selama mengikuti pembelajaran. Misal scrabble, puzzle, simulator, laboratorium, atau komputer. Masing-masing media memiliki kelebihan dan kekurangan. Antara satu media dengan media yang lain saling melengkapi.

Kriteria dalam memilih media pembelajaran tersebut, antara lain:

a. Sesuai dengan tujuan pembelajaran yang ingin dicapai

b. Tepat untuk mendukung materi pembelajaran

c. Praktis, luwes dan tahan lama

d. Guru terampil menggunakannya

e. Jumlah peserta didik

f. Mutu teknis media pembelajaran seperti ketersediaan energi listrik, cahaya di dalam ruangan.

Jadi, pilihlah media yang dibutuhkan untuk menyampaikan topik mata pelajaran, yang memudahkan peserta didik belajar, serta yang menarik dan disukai peserta didik.

Kriteria lain yang perlu dipertimbangkan antara lain:

a. apakah mudah dipahami?

b. Biayanya terjangkau?

c. Cocok dengan karakter peserta didik? Mudah digunakan dan disimpan?

d. Apakah dipandang aman untuk peserta didik?

e. Prinsip-prinsip pembelajaran anak usia dini

f. berorientasi pada kebutuhan anak

g. Belajar melalui bermain

h. Menggunakan pendekatan tematik

i. Kreatif dan inovatif

j. Lingkungan kondusif

k. Menggunakan pembelajaran terpadu

1. Mengembangkan keterampilan hidup/life skill

m. Metode pembelajaran PAUD

n. Bermain

o. Bercakap-cakap

p. Bercerita

q. Pemberian tugas

r. Eksperimen

s. Karyawisata

t. Proyek

u. Praktek langsung

v. Tanya jawab

Bisa disimpulkan, untuk pemilihan media pembelajaran dan classroom task yang baik sebaiknya disesuaikan dengan prinsip pembelajaran dan metode pembelajaran untuk anak usia dini.

\section{Classroom language}

Menurut Scott (Scott \& Ytreberg, 2004) bahasa kelas adalah ekspresi-ekspresi bahasa Inggris yang sederhana dan bermakna yang digunakan untuk membantu anakanak berkembang dari ketergantungan pada buku menjadi lebih mandiri dalam usaha untuk berkomunikasi. Pemanfaatan bahasa kelas oleh guru sangat penting dalam proses belajar mengajar agar anakanak terbiasa dalam menggunakan ekspresi-ekspresi bahasa Inggris dalam berinteraksi.

Lebih lanjut, Scott (Scott \& Ytreberg, 2004) menegaskan agar guru lebih memaksimalkan penggunaan bahasa Inggris di dalam kelas dengan menggunakan bantuan mimik, akting, boneka, dan lainlain untuk dapat menyampaikan makna. Nation (Nation, 2003) menegaskan bahwa penggunaan bahasa Inggris dalam kelas bahasa hendaknya dimaksimalkan kapan saja dan dilakukan terus menerus. Penggunaan bahasa Inggris yang maksimal di dalam kelas sangat berguna, karena anak-anak hanya mendapat kesempatan mendengar bahasa Inggris digunakan di dalam kelas. Di luar sekolah mereka biasanya kurang mendapat ekspos bahasa. Oleh karena itu, guru hendaknya mengupayakan penggunaan bahasa Inggris yang sederhana, natural dan sesuai dengan level siswa.

Contoh classroom language untuk level PAUD / TK:

a. Color!

b. Draw!

c. Dance!

d. Sing!

e. Sit down!

f. Come to the board!

Semuanya berupa ekspresi sederhana dalam kalimat pendek-pendek.

\section{B. Pembahasan Pelaksanaan kegiatan}

Kegiatan pelaksanaan pelatihan ini dilaksanakan di Ruang Kantor Desa. Tim pelaksana memberikan pelatihan dan penerangan materi serta peserta mengadakan praktek setelah pemberian materi diberikan. Narasumber yaitu tim pelaksana memberikan materi dan selanjutnya memberikan contoh-contoh media gambar baik berupa flash card maupun berupa video.

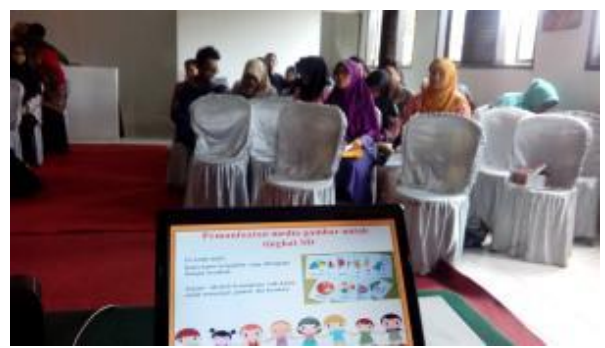

Gambar 5. Kegiatan pelatihan. 
Antusiasme para peserta dalam melaksanakan pembelajaran dengan menggunakan media gambar berupa flash card dan menggunakan bahasa Inggris cukup baik. Walaupun tidak sempurna dan beberapa masih melakukan kesalahan, namun secara umum pelaksanaan berjalan dengan baik dan lancar. Hal ini membuktikan bahwa pelatihan yang diselenggarakan mampu memacu para guru untuk mengupayakan penggunakan bahasa Inggris melalui optimalisasi pemanfaatan media gambar.

Bahkan pada akhir kegiatan peserta masih tampak antusias sehingga diharapkan bahwa kegiatan yang yang telah mereka ikut tersebut sangat bermanfaat untuk meningkatkan pengetahuan dan keterampilannya untuk melakukan inovasi-inovasi dalam pembelajaran bahasa Inggris. Acara penutupan dipandu oleh pembawa acara dengan memberikan laporan yang menyatakan bahwa kegiatan P2M tersebut berjalan dengan lancar. Pada pidato penutupannya, narasumber berharap agar apa yang telah didapatkan dan apa yang telah dilatihkan bersama-sama hendaknya terus dipraktikkan di sekolah, agar dapat meningkatkan kompetensi bahasa Inggris, baik para siswa maupun para guru sebagai peserta pelatihan tersebut.

Kriteria keberhasilan dari pelatihan ini yakni dari banyaknya peserta yang mengikuti pelatihan. Pelatihan ini dilaksanakan dengan mengundang para guru SMP dan SMA sejumlah 20 orang dan peserta yang hadir adalah 20 orang tersebut. Sehingga keberhasilan kehadiran sejumlah $100 \%$. Kemudian kriteria lain adalah meningkatnya pengetahuan dan ketrampilan para guru terkait: pengertian media, kekurangan dan kelebihan media, classroom language, desain interior TK serta pemanfaatan media gambar untuk level SD, SMP dan SMA. Untuk mengetahui efektifitas dan kebermanfaatan penyelenggaraan pengabdian ini, dilakukan juga wawancara dengan beberapa peserta setelah kegiatan pelatihan ini selesai dilaksanakan.

Hasil wawancara ini ditemukan bahwa peserta mengapresiasi materi yang diberikan. Secara umum kesulitan peserta sebagai para pengajar adalah kesulitan untuk menarik minat siswa untuk belajar bahasa Inggris karena para siswa cenderung menganggap bahwa bahasa Inggris adalah mata pelajaran yang sulit. Beberapa peserta pelatihan juga mengeluhkan sulitnya siswa untuk fokus di dalam kelas karena mereka cenderung tidak bersemangat dalam pelajaran bahasa Inggris. Peserta lain menambahkan dengan adanya media gambar ini diharapkan siswa tidak hanya menggunakan bahasa Ibu di kelas, tapi juga mulai berlatih dengan menggunakan bahasa Inggris. Dengan adanya pelatihan menggunakan media gambar ini diharapkan mereka bisa mengimplementasikannya dalam kegiatan belajar mengajar di kelas, sehingga meningkatkan motivasi dan minat belajar siswa.

\section{KESIMPULAN DAN SARAN}

\section{A. Kesimpulan}

Berdasarkan kegiatan pengabdian yang telah dilaksanakan maka simpulan yang diambil adalah sebagai berikut:

1. Pengabdian berupa kegiatan pelatihan classroom task untuk guru paud di desa palinggihan kecamatan Plered Kabupaten Purwakarta telah terlaksana dengan baik sesuai dengan jadwal.

2. Pemahaman dan pengetahuan masyarakat terutama para guru paud terkait classroom task dan implementasi media gambar telah meningkat.

\section{B. Saran}

Hal-hal yang dapat disarankan sesuai dengan simpulan di atas adalah sebagai berikut:

1. Peningkatan kualitas pembelajaran bahasa Inggris di sekolah dasar hendaknya secara terus-menerus diupayakan oleh berbagai pihak terkait, terutama oleh pihak sekolah dan guru sebagai tenaga pendidik langsung yang mengajar di dalam kelas dan berhadapan dengan siswa.

2. Guru hendaknya berusaha secara terus menerus meningkatkan kualitas pemanfaatan bahasa Inggris di dalam kelas, karena mereka adalah sumber dan model utama bahasa target yang dipelajari siswa.

3. Guru sebaiknya mengikuti perkembangan zaman teruama pemanfaatan internet agar lebih mengembangkan kemampuan pembelajaran, terutama yang berkaitan dengan media gambar.

\section{UCAPAN TERIMA KASIH}

Terima kasih disampaikan kepada IKIP SILIWANGI dan PROGRAM PENDIDIKAN BAHASA INGGRIS IKIP SILIWANGI atas berlangsungnya kegiatan pengabdian masyarakat ini.

\section{DAFTAR PUSTAKA}

AECT. (1977). The Definition Of Educational Technology. Washington: Association for Educational Communication and Technology.

Bardansyah, Y. (2008). Urgensi penciptaan lingkungan berbahasa asing.

BPS. (2015). Katalog BPS Purwakarta No 11020013214. Purwakarta: BPS.

Danim, S. (1995). Media Komunikasi pendidikan. Jakarta: Bumi Aksara.

Harmer, J. (2007). The practice of english language teaching. Essex: Pearson Education Limited.

Mahnun, N. (2012). Media pembelajaran : kajian terhadap langkah pemilihan media. Jurnal Pemikiran Islam Vol 37 No 1 UIN Suska Riau, 27-35.

Nation, P. (2003). The role of the first language in foreign language learning. Asian EFL Journal, 18.

Oktagon, T. D. (2017, September 13). The Daily Oktagon. Retrieved September 7, 2019, from The Daily Oktagon: The Daily Oktagon. "Evolusi purwakarta sebagai kabupaten moderrn dan edukasi digital". (2017). Diakses di: 
https://daily.oktagon.co.id/evolusi-purwakartasebagai-kabupaten-modern-dan-edukasi-digital/

Rahadrjo. (1986). Media pembelajaran : teknologi komunikasi pendidikan. Jakarta: Rajawali.

Schramm, W. (1982). Men, women, messages and media : understanding human communications. New York: Harper and Row.

Scott, W. A., \& Ytreberg, L. H. (2004). Teaching english to children. New York: Longman. 